\title{
The Practicality of Scrap-mod as a Learning Media on Molecular Geometry
}

\author{
Rusly Hidayah \\ Chemistry Education \\ Universitas Negeri Surabaya \\ Surabaya, Indonesia \\ ruslyhidayah@unesa.ac.id
}

\author{
Tiara Yusi Destari \\ Chemistry Education \\ Universitas Negeri Surabaya \\ Surabaya, Indonesia \\ tiaradestari@mhs.unesa.ac.id
}

\begin{abstract}
The aim of this research is to obtain the practicality of scrap-mod as a learning media on a molecular geometry matter. It is reviewed based on the activities of the students and responses of the student. This research used the R\&D (Research and Development) method which is a limited trial stage. Data collection was carried out using a students' activity observation sheet and students' responses sheet. The results of this study indicate that observing the activities of students during limited trials obtain an average percentage of $88.33 \%$ in a very good category and the responses of the students which is getting a positive percentage of $96.67 \%$ in a very good category.
\end{abstract}

Keywords—scrap-mod, media

\section{INTRODUCTION}

Education is a conscious effort and planned to create an atmosphere learning and learning process so students actively develop his potential to have strength religious spiritual, self-control, personality, intelligence, noble character, and the skills needed himself, society, nation, and country quality in the future [1]. At this time, the current curriculum that is used as an educational guide for high school graduates in Indonesia is the curriculum 2013. Based on the curriculum 2013, it recommends that the learning process with the scientific approach as the way to build knowledge, skills, and attitudes. In order to support the achievement of these three competencies, in the learning process is certainly needed media to make it easier for students [2].

The media is understood broadly is human, material or event building conditions that make students able to obtain knowledge, skills, and attitudes. In this sense, the teacher, textbook, and school environment are the media. Good media will also activate students in giving responses, feedback, and also encouraging students to apply deep learning everyday life [3]. Providing learning media is one important of educational facilities. The media is able to attract the attention of students to the lesson and play an active role in the learning process. It perhaps those students will more easily understand a chemical matter which will have a positive impact on learning outcomes [4]

Chemistry is a branch of natural science which contains a study of the structure, composition, properties, and changes in matter and energy that follow these changes [5].
Chemistry is needed in everyday life, but many people think that chemistry as a less interesting science. This is because chemistry is related to abstract concepts, so the learning of chemistry requires high reasoning [6]. Molecular geometry is a three-dimensional form of a molecule that is determined by the number of bonds and the magnitude of the angles of bonds that are around the central atom [7]. The valence-shell electron pair repulsion model (VSEPR model) provides a simple way of predicting the molecular geometries. Inparticular, the VSEPR model illustrates the bonding and nonbonding electron domains around the central atom. The bonding and nonbonding electrons experience repulsion and tend to position themselves far apart from each other [8]. The VSEPR model provides a simple way of predicting the molecular geometries. The VSEPR model gives an account of valence shell electrons of all atoms contributing to the structure [9].

In the learning process of geometry molecule matter, it requires a good enough imagination from students to imagine a molecular geometry. However, according to the results of the interviews with teacher at SMAN 1 Sidoarjo, the teacher explains molecular geometry material only used the blackboard as the media to describe a molecular geometry in one dimension. It makes difficult for students to imagine molecular geometry. Therefore, one way to encourage the achievement of effective learning especially in molecular geometry matter is to use learning aids or other media besides the blackboard, especially threedimensional media [10].

The media that are usually used to describe the geometry molecule is moly mod. Moly mod is usually made of plastic in the form of spheres connected by a bar, but based on a pre-research at SMAN 1 Sidoarjo, $61 \%$ of students said they were not familiar with moly mod. On the other hand, the results of this pre-research show that $73 \%$ of students stated that they were familiar with scrapbook handicrafts and were interested in this scrapbook. A scrap-book is the art of attaching photos or pictures on paper media that is used as books and decorate it becomes creative and interesting works. At present, there are modifications of a scrapbook in a box form, people often call it scrap-box. Based on the pre-research results, scrap-box is one of the handicrafts which are fun and 
attracted the students' attention. In the curriculum of 2013, the molecular geometry matter is learned in class $\mathrm{X}$ semester 1. This period is a transition from junior to senior high school and new students are introduced more deeply about chemistry subjects. If the students have been given funny learning, it can attract the student's attention and motivate students to study chemistry, especially molecular geometry matter. The learning process in the education unit is held in interactive, inspirational, fun, challenging, and motivating students to actively [11].

Therefore, researchers will create the media that combine moly mod with scrap-box to help and motivate students in the learning of molecular geometry matter. The media is called scrap-mod. In this regard, the use of scrapmod is expected to make learning process, especially in molecular geometry matter more enjoyable and interactive. It perhaps which the students are more motivated to learn about molecular geometry matter. It can provide deeply meaning about this matter. This is expected to make the information obtained will be kept in mind by students, and then enter into long-term memory on the brain, so it can improve the student learning outcomes in the molecular geometry matter [12].

Scrap-mod has advantages compared to moly-mod or other media on the market that is used to visualize the geometry of molecules. Scrap-mod is more innovative, creative and interesting. It also is equipped with tutorials on how to determine geometry based on VSEPR theory and practice the matter of the molecular geometry affixed to the sides of scrap-mod. In the scrap-mod, it exists with images of various molecular geometry, steps for determining molecular geometry, periodic tables, how to determine molecular geometry based on VSEPR theory, and questions about a molecular geometry matter. In addition, when the box is opened, that is a tube in the middle of scrap-mod. It is containing a set of atomic balls from styrofoamballs and spiral wire as a bond. A set of atomic balls and a spiral wire link is adapted from moly mod which is the colors of the atomic balls. Scrap-mod is also equipped with a media guidebook, so students are more easily using scrap-mod.

\section{METHOD}

This research used the Research and Development (R\&D) method. There are three main stages in this method, namely the preliminary study stage, the media development stage, and the media trial stage [13]. In the preliminary study, the stage consists of three steps, namely literature study, survey, and preparation of the initial draft. In the preparation of initial draft is carried out to produce scrapmod which can be used as a learning media based on the results of a review by experts. And then the media produced will be tested to 12 students of class X MIPA SMAN 1 Porong, Sidoarjo who have obtained molecular geometry matter. It is caused this research carried out until limited trial stage.The research and development steps are shown in Figure 1.
The limited trial stage is conducted using one grouppre-test-post-test design, which is before students using scrap-mod will be given the pre-test questions about molecular geometry and after using scrap-mod will be given a posttest question about molecular geometry. This is explained as below:

Description:

$\mathrm{O}_{1} \quad$ : A score of pre-test (before being given learning with scrap-mod)

$\mathrm{O}_{2} \quad$ : A score of a post-test (after being given learning with scrap-mod)

$\mathrm{x} \quad$ : Learning with scrap-mod [13].

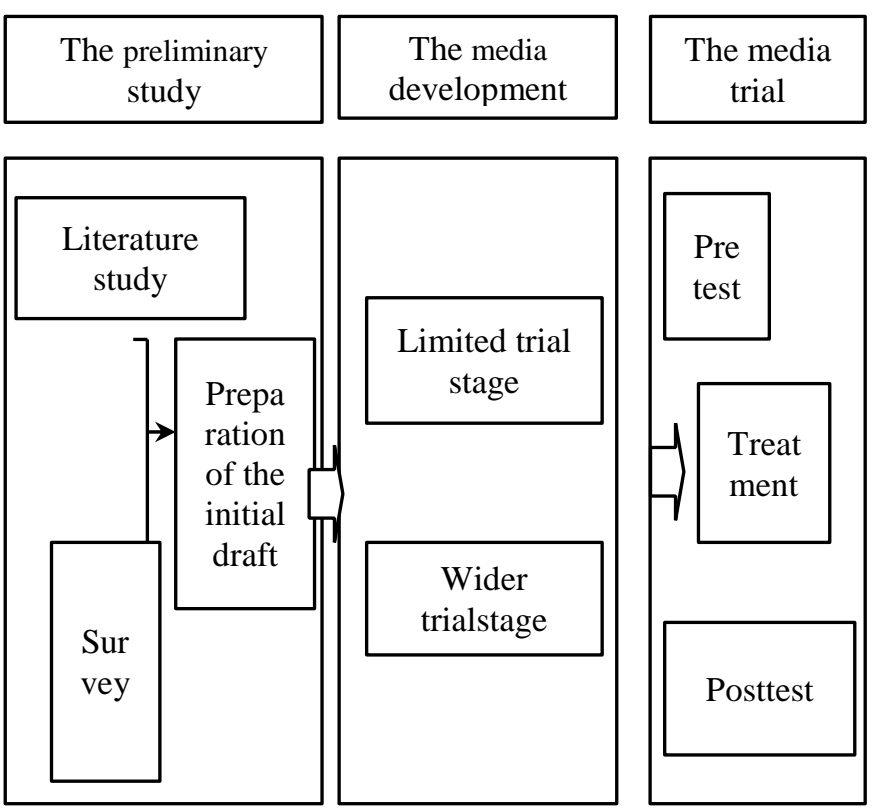

Fig. 1. Research and development steps.

\section{Analysis of Student's Activity Observation}

Observation of student activities is carried out by three observers. They filled out the student observation sheet according to the activities carried out by the students. Observation of student activities was obtained during the limited trial process of the scrap-mod application. The data is calculated based on the Guttman scale into Table 1 .

TABLE 1.GUTTMAN SCALE.

\begin{tabular}{|c|c|}
\hline Answer & Score \\
\hline Yes & 1 \\
\hline No & 0 \\
\hline
\end{tabular}

Data that got is analyzed using the calculation:

$$
\%=\frac{\text { Total of data collection }}{\text { Score of criteria }} \times 100 \%
$$

A score of the criteria

$=$ number of items $\mathrm{x}$ number of object observations.

The percentage can be categorized based on Table 2 . 
TABLE 2. SCORE INTERPRETATION CRITERIA

\begin{tabular}{|c|c|}
\hline Percentage & Criteria \\
\hline $0 \%-20 \%$ & Very less \\
\hline $21 \%-40 \%$ & Less \\
\hline $41 \%-60 \%$ & Enough \\
\hline $61 \%-80 \%$ & Good \\
\hline $81 \%-100 \%$ & Very good \\
\hline
\end{tabular}

Analysis Data of The questionnaire students' responses

Questionnaire analysis data of the student's response get after learning in molecular geometry matter using the scrapmod media. Questionnaire analysis data counts based on the modification of a Guttman scale into Table 3.

TABle 3. Modification OF a GutTMan ScAle

\begin{tabular}{|c|c|c|}
\hline Answer & $\begin{array}{c}\text { Score of positive } \\
\text { statement }\end{array}$ & $\begin{array}{c}\text { Score of negative } \\
\text { statement }\end{array}$ \\
\hline Yes & 1 & 0 \\
\hline No & 0 & 1 \\
\hline
\end{tabular}

The formula is used to calculate the questionnaire analysis data of student's responses as follow:

$\%$ of positive statement $=\frac{\text { Total of } " Y e \text { s }^{\prime} \text { answered }}{\text { number of respondent }} \times 100 \%$

$\%$ of negative statement $=\frac{\text { Total of "No" answered }}{\text { number of respondent }} \times 100 \%$

The percentage that got then it's represented into Table 2 .

\section{RESULT AND DISCUSSION}

\section{A. The Preliminary Study Stage}

At this stage consists of three steps, namely literature study, survey, and preparation of the initial draft. In the literature study step, researchers study concepts or theories relating to the media that will be developed. The theories studied are learning theory that supports learning using media, good learning media criteria, the character of students in high school age, and reviewing previous studies.

Next for the next step is a survey. The survey was taken from the results of a pre-research questionnaire to 33 students of class XI at SMAN 1 Sidoarjo which stated that molecular shape material is one of the chemical material that is considered difficult, but in reality the teacher is still dominant using the lecture method only and using the blackboard as a medium to describe molecular forms. This makes it difficult for students to learn about molecular shape material. This makes the researchers want to develop scrapmod media which is a combination of molymod and scrapbook to help students learn about molecular shape material.

Based on data obtained from library studies and field surveys, what media will be designed to be made. this is done in the third step, namely the preparation of the initial draft which will produce a draft 1 media of scrap-mod.

\section{B. The Media Development Stage}

This stage is carried out with the aim of producing scrap-mod which can be used as a learning media based on reviews by experts. This review activity was carried out several times with different objectives. These activities include review and validation activities by experts. In the review phase, the draft 1 media will be reviewed by a chemistry lecturer to get advice and input. Advice and input are needed as a reference to improve the media so that the media that has been made in accordance with established media criteria.

In the next stage, namely validation activities, the media draft that has been produced in the previous stage will be validated by two chemistry lecturers from Surabaya State University and one chemistry teacher at SMAN 1 Porong, Sidoarjo. Validity is composed of two aspects, namely content and constructs validity. From the evaluation of the three validators regarding content and construct validity, it can be concluded that scrap-mod media can be said to be feasible from the aspect of validity.

\section{The Media Trial Stage}

After the scrap-mod media developed was assessed and declared valid to be used as a learning media by the validator, then the next step was to conduct a limited trial to 12 students of class X MIPA 4 SMAN 1 Porong, Sidoarjo who had received molecular geometry matter. Limited trials were carried out to find out the practicality of the media obtained from the observation of student activities and students' response questionnaires.

\section{The Observation of Student Activities}

In the limited trial stage, students will be divided into three groups with each group consisting of four people. In this activity, there will be three observers. Each observer will observe the activities of four students or one group. Observation of this activity tries to find out the delay in testing on the molecular geometry matter using scrap-mod. The observation result of the student activities following into Table 4.

TABLE 4. The OBSERVATION Results OF THE StUdEnT ACtivity

\begin{tabular}{|l|c|r|}
\hline \multicolumn{1}{|c|}{ Activity/Criteria } & Percentage & Category \\
\hline $\begin{array}{l}\text { Knowing the student's initial } \\
\text { knowledge }\end{array}$ & $83.33 \%$ & Very good \\
\hline Know the clarity of scrap-mod & $100 \%$ & Very good \\
\hline $\begin{array}{l}\text { Knowing the interest of the } \\
\text { students in scrap-mod }\end{array}$ & $100 \%$ & Very good \\
\hline $\begin{array}{l}\text { Knowing the participation from } \\
\text { the students in learning to use } \\
\text { scrap-mod }\end{array}$ & $83.33 \%$ & Very good \\
\hline $\begin{array}{l}\text { Knowing the students' } \\
\text { knowledge about molecular } \\
\text { geometry after using scrap-mod }\end{array}$ & $66.67 \%$ & Good \\
\hline
\end{tabular}

Based on Table 4 it can be seen that there are five criteria in observing the activities of students. The first criterion is known as the student's initial knowledge about the molecular geometry matter obtained $83.33 \%$, so that it belongs to the very good category. Assessment of this 
criterion refers to the attitude of the participants who are honest in working on the pretest questions, namely whether students work on the pretest questions individually or not because the purpose of this assessment is to know the students' initial knowledge about the research material. The second criterion is to know the clarity of scrap-mod obtained by a percentage of $100 \%$, which means that the result is $\geq 61 \%$, so it belongs to the very good category. Students know how to use scrap-mod clearly, meaning students use scrap-mod media smoothly according to the instructions given.The third criterion is known the interest of the students in scrap-mod has three aspects which include students expressing feelings of pleasure in using scrap-mod, students do not complain while using scrap-mod, and students are interested in using scrap-mod. Each aspect gets a percentage of $100 \%$ and includes a very good category. This shows that $100 \%$ of students state that they are interested in scrap-mod media.The appearance of scrapmod that makes students interested is shown in Figure 2.

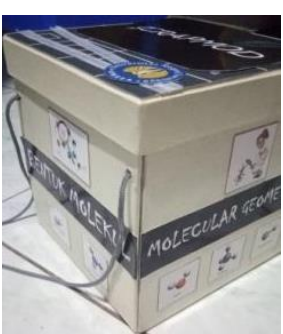

(a)

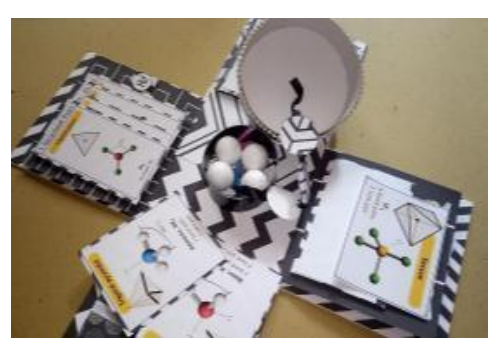

(b)
Fig.2. (a) The scrapmod display when closed; (b) The scrapmod display when opened.

The fourth criterion is to know the participation from the students in learning to use scrap-mod has four aspects including students conduct discussions between group friends, students work together to make molecular shapes from the materials provided, students answer questions that exist in scrap-mod, and students are indifferent or not busy with other activities not related to learning. In this activity, students discussed between-group friends and worked together to make molecular geometry from the materials provided. It gets a percentage of $83.33 \%$, thus indicating that students have been active in discussing and working together to make molecular shapes from the materials provided. The results of the molecular geometry made by students using scrap-mod are shown in Figure 3.

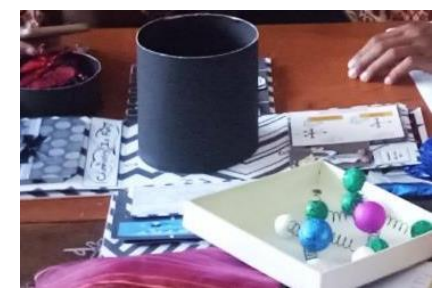

Fig.3. Molecular geometry made by students use scrap-mod.

The fifth criterion is known the knowledge of students about molecular shape material after using scrap-mod. The aspects assessed were students working on the posttest questions individually without asking for help from others, but based on observers' observations some students still saw the answers of friends and/or asked for friends, so the percentage obtained for the fifth criterion was only $66.67 \%$.

The results obtained for observation of the student activities included in the category are very good and good. The total percentage of $88.33 \%$ which can be categorized in very good criteria, so that scrap-mod media can be said to be practical as the learning media and has fulfilled one of the requirements for the feasibility of learning media. This is by the criteria of good leaning media that are practical. The learning media is said to be practical if it has a practical percentage of $\geq 61 \%$.

\section{E. The students' response questionnaires}

Questionnaire responses of students have several about criteria, there know the interest of students in scrap-mod, knowing the clarity of how to use scrap-mod, knowing the ease of use of scrap-mod, and knowing the motivation level of the students by using scrap-mod as a learning media. The student responses results following in Table 5.

TABLE 5. QUESTIONNAIRE RESPONSES OF STUDENTS RESUlT

\begin{tabular}{|l|c|l|}
\hline \multicolumn{1}{|c|}{ Criteria } & $\begin{array}{c}\text { Average of a } \\
\text { Percentage }\end{array}$ & Category \\
\hline $\begin{array}{l}\text { Knowing the interest of } \\
\text { students in scrap-mod }\end{array}$ & $100 \%$ & Very good \\
\hline $\begin{array}{l}\text { Knowing the clarity of how } \\
\text { to use scrap-mod }\end{array}$ & $94.45 \%$ & Very good \\
\hline $\begin{array}{l}\text { Knowing the ease of use of } \\
\text { scrap-mod }\end{array}$ & $91.67 \%$ & Very good \\
\hline $\begin{array}{l}\text { Knowing a motivation } \\
\text { level of the students by } \\
\text { using scrap-mod as the } \\
\text { learning media }\end{array}$ & $97.22 \%$ & Very good \\
\hline
\end{tabular}

Knowing the interest of students in scrap-mod consist of three aspects. They are scrap-mod is a funny learning media, scrap-mod is an interesting learning media, and scrap-mod design is less attractive. These three aspects have a percentage of $100 \%$ which can be categorized as very good. This shows that scrap-mod media comply with the first criteria and $100 \%$ of students are interested in scrap-mod media. Operant conditioning is a learning in which the presence of a response repeatedly will be controlled of consequences. If a person's behavior followed of pleasant consequences, then the person tends to repeat the behavior. Thus, the use of scrap-mod as a learning media is expected to make students repeat the behavior to obtain pleasant consequences that cause unconsciously the information obtained is remembered by students and entered into long-term memory in the brain [14].

Knowing the clarity of how to use scrap-mod as the second criteria has an average percentage of $\geq 81 \%$ so that it can be classified in a very good category. It has three aspects. There are the language used in scrapmod is easy to understand, a matter on scrap-mod is difficult to understand, and display on scrap-mod is compatible. The second aspect is a negative statement. 
From the results, it is obtained that the students feel the way to use scrap-mod is clear, but the understanding of each student in understanding the instructions for using a scrapmod is different. Maturity is one of the factors that influence cognitive development. The development from the system maturity of each student must vary depending on the nature of contact with the environment and self-learning activities. So that the student's understands of the language and matter inscrap-mod will be different for each person [15]

Knowing the ease of use of scrap-mod criteria gets a percentage of $91.67 \%$ and can be classified in the very good category. It shows that scrap-mod media can be said to be easy to use. This is also supported by the use of scrap-mod guidebook, so that students are easier to use scrap-mod media. This is according to the media criteria determined by Nieeven. One aspect of determining the feasibility of media is the aspect of practicality. Practicality is the criteria for the quality of learning devices in terms of the level of easiness of students in using a learning media developed [16]. The cover display of the scrap-mod guidebook is shown in Figure 4.

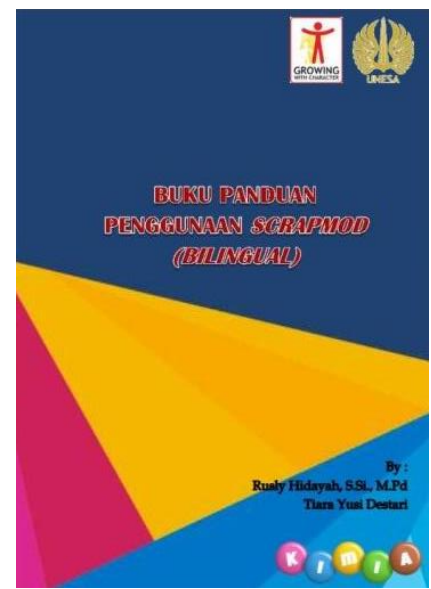

Fig. 4. Cover display of the scrap-mod guidebook

Knowing the motivation level of students by using scrap-mod as a learning media consists of three aspects, there is scrap-mod is the media that can help me learn about the molecular geometry matter, scrap-mod makes me more interested in studying chemistry, especially molecular geometry material, and I prefer learning chemistry using the media. The average percentage obtained $\geq 61 \%$. This shows that scrap-mod media has met a fourth criterion, namely the level of motivation of students using scrap-mod as a learning media can be said to be very good.

Based on the observations of the activities of the students and the questionnaire responses from students on the scrap-mod, each obtained a total percentage of $88.33 \%$ and $96.67 \%$. They got percentage of $\geq 61 \%$ in the very good category.

\section{IV.CONCLUSION}

Based on the results of the observation of students activity and the questionnaire students' responses it can be concluded that Scrap-mod is very practical used in molecular geometry matter reviewed based on:

1. The observation of studentactivities during the learning process obtains the average percentage of $88.33 \%$ with a very good category.

2. The response questionnaire given, there was a positive response with the overall percentage of $96.67 \%$ with a very good category.

\section{REFERENCES}

[1] Ministry of Education and Culture, Peraturan Menteri Pendidikan dan Kebudayaan Republik Indonesia Nomor 103 Tahun 2014 tentang Pembelajaran pada Pendidikan Dasar dan Pendidikan Menengah, Jakarta: Depdikbud, 2014.

[2] Syllabus of Chemistry Subject in High School/Madrasah Aliyah Jakarta: Ministry of Education and Culture, p.11, 2017.

[3] A. Arsyad, Media Pembelajaran, Jakarta: PT. Raja Grafindo Persada, 2010

[4] E. S. Wahyuni and R. Hidayah, "Pengembangan Permainan Chem Quartet sebagai Media Pembelajaran pada Materi Sistem Periodik Unsur Kelas X SMA Unesa,” J. Chem. Edu., vol.5, p.84, 2016.

[5] J. Untoro, Target Nilai Rapor 10 Kupas Habis Semua Pelajaran SMP/MTs Kelas VII, Jakarta: PT. Wahyumedia, 2011.

[6] A. D. Merdekawati, "Pengembangan One Step Learning Multimedia Menggunakan Software Adobe Flash pada Materi Bentuk Molekul dan Gaya Antar Molekul Kelas XI SMA,” J. Pendidik. Kimia, vol.3, p.95, 2014.

[7] Effendy, Teori VSEPR, Kepolaran, dan Gaya Antarmolekul, Malang: Bayu media publishing, 2006.

[8] R. B. Dabke and Z. Gebeyehu, Using Magnets, Paper Clips, and Ball Bearings to Explore Molecular Geometries," J. of College Sci.Teach., vol. 40, p.70, 2010.

[9] J. Mullens, H. Desseyn, and M. Herman, "Moleculer Geometry," J. Chem. Edu., vol. 62, 1985.

[10] Minister of Education and Culture Regulation Number 22 Year 2016 about Standar Proses Pendidikan Dasar dan Menengah

[11] R. E. Slavin, Educational Physhcology: Theory and Practice, ed 8, USA: Allyn Bacon, 2006.

[12] N. S. Sukmadinata, Metode Penelitian Pendidikan, Bandung: PT Remaja Rosdakarya, 2016

[13] Riduwan, Metode dan Teknik Menyusun Proposal Penelitian, Bandung: Alfabeta, 2015.

[14] M. Nur, Teori-Teori Perkembangan, Surabaya: Institut keguruan dan Ilmu Pendidikan Surabaya,1998.

[15] J. W. Santrock, Psikologi Pendidikan, ed $2^{\text {nd }}$, Jakarta: Prenada Group, 2017.

[16] N. P. T. Nieveen, Educational Design Research, Netherland: SLO, Netherlands Institute for Curriculum Development, 2013. 